\title{
Jalur Sutra Kesehatan: Upaya China Mencapai Kepentingan Geopolitik Melalui Diplomasi Vaksin
}

\author{
Gideon Candra Agape \\ UPN Veteran Jawa Timur
}

\begin{abstract}
In early April 2021, China had contributed a vital role in the Covid-19 vaccine export. With the national pharmaceutical company Sinovac and Sinopharm China capable of producing over 250 million doses of vaccine, 118 million have been successfully exported to 49 countries according to Airfinity. The world distribution of the covid-19 vaccine has been deemed a failure by the WHO, from 448 million global doses only 0.1 percent of the vaccine were administered to low-income countries, and rich countries which hold 16 percent of the world's population receiving nearly half a global dose. China is able to answer the world's frustration with the western nationalism vaccine issue, as the EU and USA failed to help low-income countries to provide vaccine access. The nationalism vaccine discourages equality, as 200 million doses of vaccine produced by the United States government had approximately exported only about 4 million doses to other countries. This paper will answer how China gains global geopolitics through vaccine diplomacy? What is the role of diplomacy in promoting China's influence? Currently China focuses on expanding its influence over Asia and South America through vaccine diplomacy, under the BRI initiative this policy is then called the Health Silk Road.
\end{abstract}

\section{Keywords: Health Silk Road, Vaccine Diplomacy, Sinovac, Sinopharm}

\begin{abstract}
ABSTRAK
Awal April 2021, Tiongkok telah berperan vital dalam ekspor vaksin COVID-19. Perusahaan negara, Sinovac dan Sinopharm China telah mampu memproduksi lebih dari 250 juta dosis vaksin, merujuk pada Airfinity, 118 juta dosis telah berhasil diekspor ke 49 negara. Distribusi vaksin global telah dinilai gagal oleh WHO, mengingat dari 448 juta dosis secara global, hanya $0,1 \%$ vaksin yang diperoleh negara dengan pendapatan rendah. Sedangkan negara kaya dengan persentase $16 \%$ dari total populasi global malah memperoleh hampir setengah dari total dosis vaksin secara global. Dalam kasus tersebut, Tiongkok berhasil menjawab permasalahan global, apalagi Uni Eropa dan Amerika Serikat gagal dalam memberikan bantuan vaksin kepada negara miskin. Program Vaksin Nasional (Nationalism Vacine) telah menghambat kesetaran akses vaksin secara global, terutama dari 200 juta dosis vaksin yang diproduksi oleh AS, hanya 4 juta dosis yang diekspor ke negara lain. Artikel ini akan berupaya untuk menjawab bagaimana Tiongkok meningkatkan posisi geopolitik global melalui diplomasi vaksin? Terutama saat ini Tiongkok berfokus pada memperoleh pengaruh ke Asia dan Amerika Selatan melalui diplomasi vaksin, di bawah BRI Initiative kini dikenal sebagai Health Silk Road
\end{abstract}

Kata Kunci: Health Silk Road, Diplomasi Vaksin, Sinovac, Sinopharm

[corresponding author: gideonagape18@gmail.com] 


\section{PENDAHULUAN}

Dunia harus menghadapi krisis kesehatan global sejak Covid-19 mulai muncul di kota Wuhan, China. Institusi Internasional seperti WHO pun dituntut untuk mampu memimpin dalam merumuskan kebijakan kesehatan global (Global Health Policy) guna memotong penyebaran virus ini. Koplan et al (2009) mendefinisikan kebijakan kesehatan global merupakan sebuah area kajian studi, penelitian, dan praktik untuk mendorong kerjasama kesehatan dunia, menekan isu-isu ketidaksetaraan akses kesehatan. Dalam argumennya Koplan menjelaskan setidaknya terdapat 5 aspek penting, yang membedakan antara global bealth, international health, dan public health, yaitu: jangkauan geografi, level kerja sama, sasaran target, akses kesehatan, rentang kajian disiplin ilmu. Banyak sekali definisi dari kebijakan kesehatan global, namun definisi dari Koplan et al mempromosikan multidisiplin ilmu, bahwasanya setiap kebijakan yang diambil merupakan proses yang melibatkan aspek ekonomi, politik, budaya, sosial, bahkan keamanan (Ana Marušic', 2013).

Tabel 1. Perbedaan kesehatan global, internasional, dan publik

\begin{tabular}{|c|c|c|c|}
\hline & Kesehatan Global & $\begin{array}{c}\text { Kesehatan } \\
\text { Internasional }\end{array}$ & Kesehatan Publik \\
\hline Cakupan geografis & $\begin{array}{l}\text { Fokus pada isu-isu } \\
\text { kesehatan global yang } \\
\text { mampu menjangkau } \\
\text { batas-batas nasional }\end{array}$ & $\begin{array}{l}\text { Fokus kepada } \\
\text { pengembangan } \\
\text { kesehatan di negara } \\
\text { miskin dan } \\
\text { berkembang }\end{array}$ & $\begin{array}{l}\text { Fokus pada isu-isu } \\
\text { kesehatan internal } \\
\text { negara yang } \\
\text { mengancam } \\
\text { keselamatan } \\
\text { masyarakat }\end{array}$ \\
\hline $\begin{array}{l}\text { Tingkatan kerja } \\
\text { sama }\end{array}$ & $\begin{array}{l}\text { Penyelesaian masalah } \\
\text { dilakukan melalui } \\
\text { kerangka kerja sama } \\
\text { global, pelibatan } \\
\text { institusi internasional, } \\
\text { seperti: WHO, GAVI, } \\
\text { CEPI, UNICEF }\end{array}$ & $\begin{array}{l}\text { Mengedepankan } \\
\text { proses kerja sama } \\
\text { bilateral atau } \\
\text { multilateral }\end{array}$ & $\begin{array}{l}\text { Penyelesaian isu } \\
\text { kesehatan melalui } \\
\text { perumusan } \\
\text { kebijakan dalam } \\
\text { negeri }\end{array}$ \\
\hline Target kebijakan & $\begin{array}{l}\text { Mencangkup program } \\
\text { perawatan medis dan } \\
\text { pencegahan penyakit } \\
\text { pada individu }\end{array}$ & $\begin{array}{l}\text { Mencangkup } \\
\text { program perawatan } \\
\text { medis dan } \\
\text { pencegahan penyakit } \\
\text { pada individu }\end{array}$ & $\begin{array}{l}\text { Melindungi populasi } \\
\text { dengan tindakan } \\
\text { pencegahan penyakit }\end{array}$ \\
\hline Akses kesehatan & $\begin{array}{l}\text { Memberikan akses } \\
\text { kesehatan secara } \\
\text { global, } \\
\text { mempromosikan } \\
\text { pelayanan kesehatan } \\
\text { sebagai barang publik }\end{array}$ & $\begin{array}{l}\text { Memberikan bantuan } \\
\text { akses kepada negara } \\
\text { miskin dan } \\
\text { berkembang dalam } \\
\text { menghadapi krisis }\end{array}$ & $\begin{array}{l}\text { Kesetaraan dan } \\
\text { keadilan akses } \\
\text { kesehatan } \\
\text { masyarakat }\end{array}$ \\
\hline $\begin{array}{l}\text { Rentang disiplin } \\
\text { ilmu }\end{array}$ & $\begin{array}{l}\text { Global Health Policy } \\
\text { adalah multidisipliner } \\
\text { ilmu, sering kali } \\
\text { melibatkan ilmuwan } \\
\text { dalam riset dan }\end{array}$ & $\begin{array}{l}\text { Riset kesehatan } \\
\text { internasional hanya } \\
\text { melibatkan beberapa } \\
\text { disiplin ilmu }\end{array}$ & $\begin{array}{l}\text { Berfokus kepada } \\
\text { ilmu kesehatan dan } \\
\text { ilmu sosial }\end{array}$ \\
\hline
\end{tabular}


otoritas dalam

menentukan kebijakan.

Sumber: Koplan et al, 2009, The Lancet

Diplomasi Vaksin merupakan sebuah titik temu dari dialog antar Hubungan Internasional dan Global Health Policy. Seperti definisi oleh dari argumen Koplan et al, yang menekankan bahwa Global Health Policy merupakan multidisipliner ilmu yang menyediakan "kursi" bagi aspek-aspek budaya, politik, ekonomi, bahkan keamanan untuk berkolaborasi. Istilah geopolitik bisa diartikan sebagai penggunaan unsur-unsur demografi untuk urusan politik demi kepentingan nasional (Ratzel, 1987). Inti teori Ratzel adalah teori ruang, yang mana unsur-unsur geografis diisi oleh aktor politik yang mengembangkan konsep ekspansionisme. Teori klasik lain yang sering dikutip adalah, Mckinder (1904) yang merumuskan penggunaan power sebagai inti teorinya, Mckinder menjelaskan barang siapa bisa menguasai jantung dunia (hearthland), dia akan mampu menguasai dunia. Namun teori klasik geopolitik cenderung power-sentric dikarenakan hubungannya dengan konteks perang dunia ke 2. Gray (1988) dalam argumennya mengatakan, bahwa teori geopolitik modern akan bergeser ke arah dimensi ekonomi, hal ini terjadi karena adanya proses perkembangan teknologi dan percepatan informasi.

Hasil analisis kami melihat bahwa geopolitik China dituangkannya pada program Belt Road Initiative (BRI), program pembangunan BRI yang dimulai sejak tahun 2013, sebuah inisiatif untuk mengembalikan jalur sutra perdagangan pada masa dinasti Han. Melalui BRI China mempromosikan kepentingannya untuk memperoleh kepentingan geopolitik, dengan memakai instrumen investasi, transfer teknologi, perjanjian perdagangan, hingga pemberian bantuan finansial (Zhang, 2018). Jalur Sutra Kesehatan merupakan salah satu bentuk implementasi BRI yang berfokus kepada pembangunan infrastruktur kesehatan (Jiahan, 2020). Awal mula diperkenalkan pada tahun 2015, kini China berupaya untuk melebarkan geopolitiknya melalui kerja sama kesehatan, pertukaran pengetahuan, peningkatan ketahanan di masa pandemi, mendorong bantuan medis, dan pembangunan riset. Jalur Sutra Kesehatan adalah upaya baru memperlebar manufaktur kesehatan China di dunia, diplomasi masker dan diplomasi vaksin merupakan implementasi dari program Jalur Sutra Kesehatan. Selaras dengan definisi geopolitik Gray (1988) yang menjelaskan pengembangan teknologi telah menggeser fokus utama geopolitik klasik. Teori interdependensi Keohane dan Nye mendukung peristiwa pergeseran fokus geopolitik, bahwa kerjasama pada bidang ekonomi akan menciptakan keterikatan antar 2 aktor yang menjalin hubungan. Dengan begini, interdependensi yang muncul karena kesepakatan internasional akan mengurangi tendensi kemunculan konflik. Namun teori ini menyajikan 2 kemungkinan, beberapa kasus kerja sama internasional hanya menguntungkan sebelah pihak. Hal ini yang kemudian menciptakan dependensi atau ketergantungan, ketika satu negara mau tidak mau harus dikontrol oleh kekuatan eksternal. Dijelaskan lebih lanjut oleh Keohane dan Nye, dependensi muncul akibat dari sensitivitas dan kerentanan aktor hubungan internasional.

Dengan teori dependensi Keohane dan Nye, kemudian spekulasi mengarah kepada upaya diplomasi China yang memanfaatkan kerentanan dan sensitivitas negara yang sedang 
dilanda oleh krisis Covid-19 untuk menciptakan ketergantungan. Dalam konteks diplomasi vaksin dan krisis Covid-19, sensitivitas diartikan sebagai kemampuan ekonomi negara untuk bertahan pada resesi global. Sedangkan kerentanan mengarah kemampuan negara mengendalikan kasus Covid-19, melakukan upaya revitalisasi dengan mencapai herd immunity. Sebuah "perlombaan lari" pun dimulai antara kapasitas produksi vaksin dan Covid-19. Misi China adalah untuk menyediakan kebutuhan vaksin sebagai barang publik global, menggelontorkan bantuan kemanusian bagi negara yang membutuhkan (Xi Jinping, 2020).

Secara jelas presiden Xi Jinping menempatkan negara-negara kecil dan negara kontributor Belt Road Intiative (BRI) sebagai sasaran dari diplomasi vaksin. Setidaknya vaksin China sudah menjangkau 80 negara dan 54 negara berkembang, dengan metode pembelian atau menerima vaksin secara gratis, dan negara berkembang lainnya membeli dengan proses bilateral (Zhao, 2021). Meskipun jelas ekspor vaksin menambah pundi-pundi ekonomi negara Tiongkok, yang diperkirakan mencapai 10 miliar dolar AS di akhir tahun 2021. Namun vaksin lebih dilihat sebagai alat diplomasi yang efektif, bukan sebagai barang komersial belaka.

\section{KERANGKA PEMIKIRAN}

Teori Ratzel adalah teori ruang, yang mana unsur-unsur geografis diisi oleh aktor politik yang mengembangkan konsep ekspansionisme. Teori klasik lain yang sering dikutip adalah, Mckinder (1904) yang merumuskan penggunaan power sebagai inti teorinya, Mckinder menjelaskan barang siapa bisa menguasai jantung dunia (bearthland), dia akan mampu menguasai dunia. Namun teori klasik geopolitik cenderung power-sentric dikarenakan hubungannya dengan konteks perang dunia ke 2. Gray (1988) dalam argumennya mengatakan, bahwa teori geopolitik modern akan bergeser ke arah dimensi ekonomi, hal ini terjadi karena adanya proses perkembangan teknologi dan percepatan informasi.

Teori interdependensi Keohane dan Nye mendukung peristiwa pergeseran fokus geopolitik, bahwa kerjasama pada bidang ekonomi akan menciptakan keterikatan antar 2 aktor yang menjalin hubungan. Dengan begini, interdependensi yang muncul karena kesepakatan internasional akan mengurangi tendensi kemunculan konflik. Namun teori ini menyajikan 2 kemungkinan, beberapa kasus kerja sama internasional hanya menguntungkan sebelah pihak. Hal ini yang kemudian menciptakan dependensi atau ketergantungan, ketika satu negara mau tidak mau harus dikontrol oleh kekuatan eksternal. Dijelaskan lebih lanjut oleh Keohane dan Nye, dependensi muncul akibat dari sensitivitas dan kerentanan aktor hubungan internasional.

\section{HASIL DAN PEMBAHASAN}

\section{A. Vacuum of Control}

Kekosongan peran yang ditinggalkan oleh Uni Eropa dan AS dalam ekspor vaksin global, memunculkan isu nasionalisme vaksin (Gruszczynski dan Wu, 2021). "Jendela" hubungan diplomatik antara China dan negara-negara berkembang pun terbuka lebar, beberapa aktor besar lainnya juga tergabung, yaitu Rusia dan India sebagai pemimpin dari perlombaan diplomasi vaksin. Namun India yang semula merupakan salah satu pemain kunci 
diplomasi vaksin, harus menunda kebijakan luar negerinya demi memenuhi kebutuhan vaksin dalam negeri karena lonjakan kasus, hal ini kemudian berdampak pada distribusi vaksin dunia (Gupta, 2021) . Adhanom Ghebreyesus, direktur Organisasi Kesehatan Dunia melihat nasionalisme vaksin merupakan istilah, untuk menggambarkan langkah mengamankan pasokan vaksin bagi kebutuhan dalam negeri. Dalam jangka pendek, nasionalisme vaksin akan mempercepat proses revitalisasi ekonomi yang sempat terhenti oleh pandemi, kemudian vaksin juga akan mengamankan ketahanan nasional.

Tabel 2. Daftar dosis pembelian vaksin negara-negara maju dengan perusahaan farmasi

\begin{tabular}{|c|c|c|}
\hline NEGARA & $\begin{array}{c}\text { JUMLAH } \\
\text { KESEPAKATAN DOSIS }\end{array}$ & JENIS VAKSIN \\
\hline Amerika Serikat & 300 Juta Dosis & AstraZeneca \\
\hline Inggris & 90 Juta Dosis & AstraZeneca \\
\hline Amerika Serikat & 10 Juta Dosis & Novavax \\
\hline Jepang & 120 Juta Dosis & AstraZeneca \\
\hline Jepang & 120 Juta Dosis & Pfizer BioNTech \\
\hline Kanada & 120 Juta Dosis & Moderna \\
\hline Inggris & 60 Juta Dosis & Novavax \\
\hline Inggris & 40 Juta Dosis & Pfizer/BioNTech \\
\hline Inggris & 60 Juta Dosis & Sanofi GSK \\
\hline Kanada & 76 Juta Dosis & Medicago \\
\hline Kanada & 76 Juta Dosis & Novavax \\
\hline Kanada & 72 Juta Dosis & Sanofi GSK \\
\hline Kanada & 56 Juta Dosis & Pfizer BioNTech \\
\hline Kanada & 38 Juta Dosis & $\begin{array}{l}\text { Janssen Pharmaceutical } \\
\text { Companies }\end{array}$ \\
\hline Kanada & 20 Juta Dosis & AstraZeneca \\
\hline Kanada & 20 Juta Dosis & Moderna \\
\hline Amerika Serikat & 100 Juta Dosis & Pfizer BioNTech \\
\hline Amerika Serikat & 100 Juta Dosis & Moderna \\
\hline Amerika Serikat & 100 Juta Dosis & Sanofi GSK dan J\&J \\
\hline Uni Eropa & 400 Juta Dosis & AstraZeneca \\
\hline Uni Eropa & 300 Juta Dosis & Johnson \& Johnson \\
\hline Uni Eropa & 300 Juta Dosis & Sanofi GSK \\
\hline Uni Eropa & 300 Juta Dosis & Pfizer BioNTech \\
\hline
\end{tabular}

Sumber: Vox, Bloomberg, Atlas Magazine, New York Times tahun 2020

Meskipun COVAX menyediakan mekanisme Advance Market Commitment (AMC) untuk negara miskin dan berkembang, yang berarti negara-negara ini akan mendapat jumlah $20 \%$ dosis suntikan vaksin dari total populasi (GAVI, 2021). Perlu diketahui bahwa negaranegara berkembang masih harus berada di " antrean nomor dua", menunggu setidaknya hingga tahun 2022 atau bahkan tahun 2023 (Vox, 2021). Negara-negara kaya melakukan proses kerja sama langsung dengan perusahaan farmasi. Seperti Contohnya, Amerika Serikat memberi suntikan dana sebanyak 1.2 miliar dolar AS kepada AstraZeneca, dengan begitu AS akan mengamankan 300 juta dosis suntikan untuk vaksin ini. Beberapa negara maju seperti 
Kanada, Israel, Inggris, Jepang melakukan kesepakatan langsung dengan perusahaan farmasi. Jutaan dolar yang digelontorkan juga akan menentukan kemana arah vaksin akan distribusikan. Tentu negara berkembang dan negara miskin tidak punya kemampuan yang sama dalam hal ini.

Diplomasi vaksin bukan sesuatu yang benar-benar baru, namun banyak ahli mengartikulasikan diplomasi vaksin erat dengan konteks pandemi Covid-19. Kickbusch et al (2013) mendefinisikan posisi yang mana masyarakat dan pemerintah mengimplementasikan kesehatan publik ke arah kebijakan luar negeri, membentuk negosiasi baru terkait global health governance. Kemudian Global Health Diplomacy dibagi menjadi setidaknya 3 bagian penting oleh Kazt et al. (1) Core Diplomacy merujuk pada sistem Westphalia klasik, saat dimana negosiasi masih kental akan nuansa state centric, negara menjadi aktor utama pemimpin diplomasi. Core diplomacy akan mengarahkan aktor pada hubungan langsung secara multilateral atau bilateral. (2) Multistakeholder Diplomacy, melibatkan negara dan agensi internasional, contohnya adalah WHO, GAVI, CEPI, dan COVAX. (3) Informal Diplomacy, melibatkan proses negosiasi antara pemerintah dengan sektor privat secara langsung.

China telah menjual sebanyak setengah miliar lebih dosisnya kepada negara di dunia, tinggal menunggu waktu vaksin yang dipesan sampai di negara penerima (Wu, 2021). Dua vaksin utama China memberi prospek yang menjanjikan, misalnya: Sinopharm memiliki tingkat keberhasilan 79 \%-86 \% dan Sinovac 50\% -84 \%. Awalnya dunia dibuat skeptis akan tingkat keberhasilan Sinovac, namun kembali China memperoleh kepercayaan ketika WHO memberikan lisensi kepada vaksin China untuk penggunaan darurat (Mallapaty, 2021). China memainkan 2 buah peran, secara masif China melakukan ekspansi diplomasi vaksin ke negara-negara berkembang melalui proses bilateral, dan hingga kini Russia merupakan kompetitor yang melakukan hal yang sama. Diplomasi vaksin melalui perjanjian bilateral merupakan implementasi dari core diplomacy yang disampaikan oleh Kazt.

COVID-19 V accines Global Access (COV AX) merupakan aliansi kesehatan global yang dipimpin oleh Global Alliance for Vaccines and Immunization (GAVI), Coalition for Epidemic Preparedness Innovations (CEPI), World Health Organization (WHO), dan UNICEF. Saat ini inisiasi COVAX telah menggandeng 190 negara, misi COVAX adalah memberikan akses kepada 92 negara berkembang, dengan estimasi 2 miliar dosis akan selesai diproduksi di akhir tahun 2021. Wigmore (2021) berpendapat bahwa kebijakan diplomasi vaksin China merupakan perpanjangan jebakan hutang yang dibawa dari BRI (Belt Road Iniative). Implikasinya, beberapa negara di Asia Tenggara melakukan diversifikasi vaksin agar tidak sepenuhnya bergantung pada China. Jebakan hutang identik dengan jatuhnya pelabuhan Hambantonta di Sri Lanka, namun seperti yang ditemukan Rowley (2020) hal yang terjadi di Sri Lanka lebih banyak menggambarkan pengelolaan dana yang buruk pemerintah dan memperlihatkan sedikit bukti bahwa China dengan "sengaja" menjebak Sri Lanka. Sejak awal dipublikasikan, spekulasi tentang diplomasi vaksin China terus bermunculan, terutama kritikan dari Barat yang mencoba memberi tahu agar berhati-hati dengan kebijakan luar negeri China. 


\section{B. Diplomasi Vaksin menuju ASEAN, Amerika Latin, dan Afrika}

China memastikan langkahnya dengan melakukan perjanjian bilateral ekspor vaksin pada negara anggota ASEAN. Total 9 dari 10 negara (kecuali Vietnam) telah mendapat bantuan vaksin Sinopharm dan Sinovac dari China (Karásková dan Blablová, 2021). China mulai memantapkan langkahnya kembali, melalui pendekatan program ASEAN Comprehensive Framework, China ingin mendukung penuh upaya-upaya negara-negara di ASEAN seperti contohnya Indonesia dan Filipina untuk mulai memproduksi vaksinnya sendiri. Beberapa ahli geopolitik Asia Selatan melihat aksi China merupakan sebuah smoking screen, China mencoba melakukan rebranding negaranya yang sempat menjadi penyebab masalah sebagai pemberi solusi. Namun hal ini juga tidak mudah, langkah yang dilakukan China harus hatihati karena beberapa negara ASEAN juga memutuskan untuk membatasi ketergantungan mereka terhadap vaksin China. Hal ini juga merupakan sikap antisipasi, meskipun cenderung spekulatif beberapa pihak melihat, China ingin ASEAN bersikap lunak terhadap konflik Laut China Selatan (Yeremia dan Raditio, 2020)

Tabel 3. Jumlah vaksin yang didapat dan diekspor oleh negara pada bulan Maret 2021

\begin{tabular}{|l|c|c|}
\hline \multicolumn{1}{|c|}{ NEGARA } & $\begin{array}{c}\text { TOTAL VAKSIN YANG } \\
\text { DIDAPAT }\end{array}$ & $\begin{array}{c}\text { TOTAL VAKSIN YANG } \\
\text { DIEKSPOR }\end{array}$ \\
\hline Amerika Serikat & 164 juta dosis & - \\
\hline China & 229 juta dosis & 109 juta dosis \\
\hline India & 125 juta dosis & 55 juta dosis \\
\hline Uni Eropa & 110 juta dosis & 46 juta dosis \\
\hline Inggris & 16 juta dosis & - \\
\hline
\end{tabular}

Sumber: Airfinity 2021

Namun kami setuju bahwa, diplomasi vaksin telah diterjemahkan dalam perspektif yang sempit, mengingat tujuan utama presiden Xi Jinping adalah menyediakan vaksin sebagai barang publik global. Diplomasi vaksin tidak akan terlalu berdampak kepada resolusi konflik Laut China Selatan, bahwa beberapa negara seperti Indonesia dan Filipina contohnya, mengambil sikap yang bulat, di tahun 2020 pemerintah Indonesia memberikan catatan kepada Sekjen PBB bahwa pemerintah secara tegas menolak klaim China. Filipina pun bertindak demikian, meskipun China sangat membantu dalam pemberian vaksin, namun permintaan China ke Filipina untuk menarik pasukan patroli di LCS tidak bisa dipenuhi (Grossman, Foreign Policy, 2021). Investasi, peningkatan manufaktur, dan penjalinan kerjasama merupakan tujuan utama China. Beberapa negara dipaksa memutar strategi untuk mendapat pasokan pengganti vaksin dari Institut Serum India yang sedang berhenti sementara. Melalui PT Bio Farma dan Sinopharm, Indonesia mulai untuk menambah kuota vaksin China, dan upaya pengembangan manufaktur Vaksin Covid-19 adalah misi China untuk menjadikan Indonesia sebagai negara pemasok vaksin ASEAN.

Afrika juga memerlukan proporsi yang sama untuk mencapai kekebalan populasi, 54 negara di benua ini butuh setidaknya 60 persen jumlah vaksin dari total populasi. Jika setiap masyarakat memerlukan 2 dosis suntikan, berarti dari total 1,3 miliar jiwa yang ada di Afrika, benua ini memerlukan 1,6 miliar dosis untuk mencapai herd immunity. Setelah gagalnya distribusi vaksin global, yang mana hampir separuh dari total vaksin dunia jatuh ke negara 
maju yang hanya mencangkup 16 persen populasi global, sedangkan Afrika hanya menerima kurang dari persen vaksin global yang sudah dibagi. Negara miskin memerlukan dukungan, China merupakan opsi terbaik, mengingat pandemi adalah tentang perlombaan waktu, sebelum virus ini menjangkit semakin banyak orang dan bermutasi menjadi varian baru.

Sebelum vaksin ditemukan, China sendiri sudah memulai diplomasi masker, bantuan berupa masker, ventilator, alat pelindung diri, alat tes Covid-19 hingga tenaga kerja sudah dikirimkan China di benua Afrika. Diplomasi vaksin adalah bentuk konsistensi bantuan yang dikirimkan oleh China. Statistik di bulan Maret-Mei 2020 memperlihatkan kontribusi China dalam penyediaan perlengkapan medis Covid-19. China berhasil menyediakan 70.6 miliar masker, 340 juta alat pelindung diri, 115 juta kacamata medis, 96, 700 ventilator, 225 juta test kits, dan 40,29 juta termometer infrared untuk negara berkembang di dunia.

China memegang 16 persen total investasi di Afrika tahun 2018, hal ini sekaligus menjadikan China sebagai negara pemegang investasi terbesar di benua itu. Diplomasi vaksin di Afrika merupakan langkah konsisten China dalam membantu negara-negara di Afrika. Fakta bawah 10.000 perusahaan China kini berdiri di Afrika, hingga personel medis China telah merawat 220 juta jiwa di 48 negara Afrika melalui 21000 tenaga medis yang sudah dikirimkan (Wang Yi, 2020). Kerentanan seperti yang disampaikan oleh Keohane dan Nye terlihat jelas di Afrika, semua negara di benua ini harus menunggu sampai tahun 2022 atau bahkan 2023 agar populasi bisa terbebas dari virus sepenuhnya. China siap untuk menolong kerentanan Afrika dalam suplai vaksin. Ketimpangan terlihat nyata, kini Amerika Serikat telah menerima 250 juta dosis vaksin, di bulan Mei 2021 bahkan pemerintah telah satu kali menyuntikan 150.4 juta dosis vaksin termasuk 110 juta orang dengan suntikan dosis tunggal, dan Joe Biden akan menyelesaikan rencananya untuk menyuntik 70 persen orang dewasa pada bulan Juli.

Hingga saat total ekspor vaksin China ke Afrika sudah menjangkau ke 19 negara berkembang, menyentuh angka 12.3 juta dosis (Bridge Beijing, 2021). Afrika akan diberi bantuan sebanyak 600 juta dosis di akhir tahun 2021 melalui COVAX. Kemudian African Vaccine Acquisition Task Team (AVATT) sebuah program penyediaan vaksin di Afrika yang diinisiasi oleh Uni Afrika juga sudah mengamankan pesanan sebanyak 670 juta dosis AstraZeneca. Tapi anomali lonjakan kasus yang terjadi di India, harus menghentikan rencana AVATT, Serum Institute of India (SII) tidak akan mengekspor vaksin AstraZeneca untuk sementara, setidaknya hingga beberapa bulan. China kembali mendapat peluang besar untuk menjalankan Jalur Sutra Kesehatannya, vaksin Sinopharm terbukti lebih adaptif terhadap kondisi iklim di benua Afrika, jika dibandingkan kan dengan vaksin Barat. Vaksin Sinopharm adalah vaksin non-aktif menggunakan cara yang lebih tradisional dari teknologi mRNA, vaksin ini tidak perlu lemari pendingin dengan kapasitas -20 derajat atau -70 derajat Celsius. Kapasitas kesehatan di negara berkembang tentu terbatas akan penyediaan lemari pendingin ini.

Di Amerika Latin China juga berusaha memperkuat perjanjian bilateral dengan Mexico, Brasil, Chile, Peru dan beberapa negara lainnya. Skema yang ditawarkan oleh China hampir sama, memberikan dosis suntikan vaksin berupa donasi atau melalui penjualan. Lü Xiang (2021) peneliti studi Amerika Serikat CASS (Chinese Academy of Social Sciences) berargumen bahwa Amerika Serikat khawatir akan kehilangan halaman belakangnya 
(Amerika Latin). Oleh sebab itu diplomasi vaksin yang dilakukan China diterjemahkan sebagai upaya politik saja, alih-alih bantuan kemanusiaan untuk Covid-19. Perjanjian bilateral vaksin adalah upaya untuk menguatkan hubungan China dengan negara sasaran, namun proses ini merupakan tahap awal. Proses FDI, R\&D dan Outsourcing merupakan instrumen penting untuk memperlebar manufaktur farmasi China. Kepentingan pelebaran manufaktur inilah yang menjadi tujuan penting China, bahwa negara ini menggandeng aktor-aktor kunci kawasan, mendukung mereka untuk menjadi distributor baru atau bahkan produsen baru vaksin Sinopharm, Sinovac, dan Cansino. Terlebih lagi dukungan ini tidak hanya berfokus pada sekedar hubungan bilateral, China mengamankan langkahnya secara hati-hati dan mengaplikasikannya pada program kerja kawasan. Di ASEAN China mengimplementasikan diplomasi vaksin pada program Regional Comprehensive Economic Partnership (RCEP) atau program kerjasama perdagangan bebas Asia Pasific serta ASEAN Comprehensive Recovery Framework (ACRF). Dengan demikian China bisa lebih leluasa bekerja mempromosikan diplomasi vaksin, tanpa harus menonjolkan sisi hegemoninya.

Paraguay menjadi salah satu destinasi penting bagi diplomasi vaksin China. Paraguay adalah satu dari 15 belas negara yang mengakui Taiwan sebagai negara berdaulat, Taiwan menuduh China menggunakan vaksin sebagai alat politik agar Paraguay melepaskan hubungan dengan Taipei (Londoño, 2021). Menteri Luar Negeri Paraguay, Acevedo Euqlides (2021) menjelaskan bahwa akan membangun kerja sama dengan China yang mempunyai prospek kepada peralihan hubungan diplomatik.

Diplomasi vaksin China di Brasil juga membuahkan efek spillover. Brasil bersama Amerika Serikat dibawah pemerintahan Trump, telah berkomitmen untuk membangun infrastruktur jaringan 5G yang aman tanpa spionase China. Kunjungan Menteri Komunikasi Brazil, Fábio Faria, meminta vaksin yang dituntut oleh rakyat Brasil.. Krisis Covid-19 telah memutar balikan keadaan, bahwa sebelumnya Huawei berada di daftar hitam investor. Namun setelah dosis pertama vaksin China sampai di Brazil pada bulan Februari, Badan Pengatur Telekomunikasi mengumumkan bahwa lelang 5G yang diadakan di bulan Juli tidak menempatkan Huawei pada daftar hitam (Londoño dan Casado, 2021).

Selanjutnya China juga bekerja dibawah koridor program South-South Cooperation dalam kerja sama membantu negara berkembang di Afrika dan Amerika Latin. Bahwa program ini jelas mempunyai tujuan untuk membantu negara-negara berkembang dengan proses pembangunan infrastruktur, transfer teknologi, dan pertukaran sumber daya. Bisa dikatakan China berhasil mengamankan aktor kunci di setiap jalur diplomasi vaksinnya. Indonesia sebagai salah satu negara kunci ASEAN akhirnya mulai memproduksi vaksinnya, dengan bahan yang dikirim dari perusahaan Sinovac China. Indonesia mengamankan 142 juta dosis berupa bahan mentah yang akan dikirim bertahap, tidak hanya itu Indonesia menambah kuota bahan mentah yang menjadikan total semua 260 juta dosis Sinovac.

Di Afrika China menggandeng Maroko, Mesir, dan Ethiopia untuk menjadi produsen vaksin Sinovac di Afrika. Seperti contohnya, China memberikan lisensi terbatas kepada perusahaan Mesir Vacsera untuk mulai memproduksi vaksin lokalnya sendiri. Dengan pengaturan dan bahan mentah yang dikirim China, Mesir akan mampu memproduksi 80 juta dosis di tahun 2021. Bergeser di sisi selatan dunia yang lainnya, Mexico adalah negara pertama yang menerima Cansino untuk diproduksi dalam negeri. Pemerintah telah menandatangani 
35 juta dosis Cansino di bulan Maret 2021, dan saat ini Mexico telah memiliki cukup bahan aktif untuk memproduksi 5 juta dosis. Tujuan Mexico untuk menyediakan ketahanan vaksinnya sendiri daripada harus terikat dengan hubungan internasional, hal ini juga buah dari kekecewaan vaksin barat. Bahkan Brasil mulai melakukan perjanjian vaksin dipimpin oleh provinsi Sao Paulo, provinsi ini menandatangani 46 juta dosis vaksin Sinovac tanpa persetujuan otoritas Brasil. Butantan Institute akan menjadi eksekutor dari produksi vaksin Sinovac.

Saat ini manufaktur farmasi China memegang sekitar 11 persen penjualan global, diperkirakan manufaktur China akan memegang 30 persen penjualan Global dengan kisaran nilai 161,8 miliar dolar AS di tahun 2023 (Alisson, 2021). Sangat jauh jika dibandingkan dengan Amerika Serikat, di tahun 2018 negara ini memegang 40 penjualan farmasi global. Alisson (2021) dalam hasil analisisnya, menyebutkan bahwa perusahaan farmasi China mengandalkan instrumen $R \& D$ dan investasi untuk melebarkan pasar. Hal ini tercermin dengan apa yang dilakukan oleh Sinovac, Sinopharm, dan Cansino dengan membuka jaringan manufaktur, melepaskan lisensi terbatas agar negara sasaran mampu memproduksi vaksinnya sendiri.

\section{KESIMPULAN}

China harus segera menyelesaikan misinya dalam diplomasi vaksin, keunggulan yang didapat China dari kekosongan kursi yang ditinggalkan AS, Uni Eropa, dan India hanya akan bertahan sementara. Saat ini pesaing utama China adalah perusahaan Sputnik V asal Rusia. Kerja sama 4 negara antara AS, Jepang, Australia, dan Kanada akan kembali di akhir tahun 2022, membawa sekitar 1 miliar dosis kedalam perlombaan vaksin. Memang benar saat ini Presiden Amerika Serikat, Joe Biden, berhasil menyelesaikan 100 hari pertama dengan menyuntik 150 juta warganya (Murphy, 2021), namun kebijakan "America First” membuat AS jauh tertinggal dari Rusia dan China dalam diplomasi vaksin global. Saat ini dinamika perlombaan diplomasi vaksin, adalah solusi menyelamatkan negara miskin dari isu nasionalisme vaksin Barat (Gruszczynski dan Wu, 2021).

Diplomasi vaksin merupakan bentuk soft power China yang digunakan untuk menjalin keterikatan (Ellwood, 2021). Dalam penjelasan Wilson (2008, hal 114), soft power adalah kekuatan untuk membujuk pihak demi tujuan kepentingan negara. Lebih lanjut Nye (2004a, hal 5) menjelaskan fungsi soft power untuk membangun ketertarikan, agar pihak lain mau melakukan apa yang diinginkan oleh negara. Membentuk relasi dari soft power juga memerlukan proses yang panjang, berbeda dengan konsep hard power yang menggunakan paksaan agar mendapat hasil secara cepat. Cooper (2004, hal 170) menambahkan bahwa terkadang negara tidak mampu mengontrol sepenuhnya hasil dari soft power. China yang diduga ingin mempengaruhi negara-negara ASEAN mengenai konflik Laut China Selatan, mendorong kerjasama vaksin ASEAN saat negara barat sibuk menyuntik masyarakatnya sendiri. China belum berhasil mendapatkan hasil yang positif terkait isu LCS, memang diplomasi kesehatan berada pada dimensi low politics dan akan membutuhkan usaha lebih agar vaksin China bisa memperkuat klaim China di LCS. 


\section{DAFTAR PUSTAKA}

Amstrong, Drew dan Tom Randall. (2020). U.S. Ranks Behind EU, Australia, U.K. in Vaccine Buys But Says It Will Meet Goal. Bloomberg. Diakses 8 Mei, tersedia di https://www.bloomberg.com/news/articles/2020-12-09/which-countries-havereserved-the-most-covid-19-vaccines-u-s-is-32nd-on-list

Bassin, Mark. (1987). Imperialism and the nation state in Friedrich Ratzel's political geography. https://doi.org/10.11772F030913258701100401

BBC news. (2021). Sinovac: Brazil results show Chinese vaccine 50.4\% effective. Diakses 6 Mei, tersedia di https://www.bbc.com/news/world-latin-america-55642648

Benabdallah, Lina. (2021). Don't believe the hype about China's 'vaccine diplomacy' in Africa. The Washington Post. Diakses pada 7 Mei 2021 tersedia di https://www.washingtonpost.com/politics/2021/03/05/dont-believe-hype-aboutchinas-vaccine-diplomacy-africa/

Bogdan, Taylor Basrowi, dan Suwandi. (2008). Memahami Penelitian Kualitatif, Jakarta: Rineka Cipta.

Bridge Beijing. (2021). China Covid-19 Vaccine Tracker. Diakses pada 6 Mei 2021 tersedia pada https://bridgebeijing.com/our-publications/our-publications-1/china-covid19-vaccines-tracker/

Creswell, J. W. (2013). Research Design Pendekatan Kualitatif, Kuantitatif, dan Mixed. Yogyakarta: Pustaka Pelajar

Development Reimagined. (2021). It's Been One-Year Since the First COVID Case in Africa: China's Contribution \& COVID Year in Review. The China Africa Project. Diakses pasa 5 Mei, tersedia di https://chinaafricaproject.com/analysis/its-beenone-year-since-the-first-covid-case-in-africa-chinas-contribution-covid-year-inreview/

Gavi. (2021). THE GAVI COVAX AMC AN INVESTMENTOPPORTUNITY. Diakses pada 7 Mei tersedia di https://www.gavi.org/investment-opportunity-gavi-covaxamc\#: :text=Back20to-

,Gavi20COVAX20AMC20Investment20Opportunity,continue20at20an20accelerat ed20pace.

Gray. S. J. (1988). Towards a Theory of Cultural Influence on the Development of Accounting Systems Internationally. Abacus Vo. 24, Issue 1 p. 1-15. https://doi.org/10.1111/j.1467-6281.1988.tb00200.x

Greif, Mariana. (2021). China's COVID-19 vaccine production capacity may cover $40 \%$ of population by mid-2021: disease control head. Reuters. Diakses pada 7 Mei tersedia di https://www.reuters.com/article/us-health-coronavirus-china-vaccineidUSKBN2AX1KS

Gruszczynski, Lukasz dan Chien-huei Wu. (2021). Between the High Ideals and Reality: Managing COVID-19 Vaccine Nationalism. Cambridge University Press. Diakses pada 6 Mei tersedia di https://doi.org/10.1017/err.2021.9 
Harris, Richard L. and Arias, Armando A., (2016). "China's South-South Cooperation with Latin America and the Caribbean". SBGS Faculty Publications and Presentations. 24. https://digitalcommons.csumb.edu/sbgs_fac/24

Hotez. J Pieter. (2014). Vaccine Diplomacy: Historical Perspectives and Future Direction. Diakses pada 7 Mei 2021, tersedia di https://www.ncbi.nlm.nih.gov/pmc/articles/PMC4072536/\#!po=0.684932

Jiahan, Ciao. (2020). Toward A Health Silk Road: China’s Proposal for Global HealthCooperation. World Century Publishing Corporation and Shanghai Institutes for International Studies. Vol. 6, No. 1, 19-35. DOI: 10.1142/S2377740020500013

Katz, R, dan Scott F Dowell. (2015). "Revising the International Health Regulations: Call for a 2017 Review Conference." The Lancet Global Health. Diakses 7 Mei https://www.thelancet.com/journals/langlo/article/PI-IS2214-109X(15)00025$\mathrm{X} /$ fulltext.

Kickbusch I, Silberschmidt G, Buss P. (2007). Global health diplomacy: the need for new perspectives, strategic approaches and skills in global health. Bull World Health Organ 85: 230-232

Kiernan, Samantha et al. (2021). The Politics of Vaccine Donation and Diplomacy: Is a Friend Need a Friend Indeed ?. Think Global Health. Diakses pada 7 Mei 2021, tersedia di https://www.thinkglobalhealth.org/article/politics-vaccine-donationand-diplomacy

Kollewe, Julia. (2021). "Pharmaceuticals industryFrom Pfizer to Moderna: who’s making billions from Covid-19 vaccines?". The Guardian. Diakses 6 Mei, tersedia di https://www.theguardian.com/business/2021/mar/06/from-pfizer-to-modernawhos-making-billions-from-covid-vaccines

Lamont, C. (2015). "Research Methods in International Relations", ISBN: 9781446286050. New York: Sage Publication Ltd.

Li, Hangwei dan Jacqueline Musiitwa. (2020. Coronavirus diplomacy': China's opportune time to aid Africa. The Africa Report. Diakses pada 7 Mei, tersedia di https://www.theafricareport.com/26750/coronavirus-diplomacy-chinasopportune-time-to-aid-africa/

Mallapaty, Smriti. (2021). China's COVID vaccines are going global — but questions remain. Nature. Diakses pada 7 Mei, tersedia di https://doi.org/10.1038/d41586021-01146-0

McKinder, H. J. (1904). The Geographical Pivot History. The Geographical Journal, Vol. 170, No. 4, December 2004, pp. 298-321. Blackwell Publishing Ltd.

Nye, J. (1987). Power and Interdependence Revisited. International Organization, 41(4), 725-753. Diakses pada 9 Mei tersedia di https: // www. jstor .org / stable / 2706764

Pharma China. (2016). China Pharmaceutical Guide 2016.

Twohey, Megan et al. (2020). With First Dibs on Vaccines, Rich Countries Have 'Cleared the Shelves'. The New York Times. Diakses pada 5 Mei, tersedia di https://www.nytimes.com/2020/12/15/us/coronavirus-vaccine-dosesreserved.html?0p19G=2103 
WHO. (2017). China Policies to Promote Local Production of PharmaceuticalProducts and Protect Public Health. ISBN 978-92-4-151217-6. Diakses pada 7 Mei tersedia di https://www.who.int/phi/publications/2081China020517.pdf?ua=1

Wigmore, Rosie. (2021). 5 Reasons to Worry About the 'Chinese Vaccine Diplomacy' Narrative. The Diplomat. Diakses pada 7 Mei tersedia di https:/ thediplomat.com/2021/03/5-reasons-to-worry-about-the-chinese-vaccinediplomacy-narrative/

Wu, Huizhong dan Kristen Gelineau. (2021). Chinese Vaccines Sweep Much of the World, Despite Concerns. The Diplomat. Diakses pada 8 Mei 2021, tersedia di https://thediplomat.com/2021/03/chinese-vaccines-sweep-much-of-the-worlddespite-concerns/

Wu, Huizhong. (2021). China to donate 10M coronavirus vaccine doses to developing nations. The Associated Press. Diakses pada 7 Mei tersedia di https://globalnews.ca/news/7616838/china-covax-donationcoronavirus $7616838 / \mathrm{amp} /$

Xin, Liu et all. (2021). China deepens anti-COVID19 cooperation with S. Asian nations amid surging cases in India. The Global Times. Diakses pada 5 Mei 2021, tersedia di https://www.globaltimes.cn/page/202104/1222292.shtml

Yang, William. (2021). COVID-19: Why is China's vaccination rate so low?. Deutsche Welle. Diakses pada 7 Mei 2021, tersedia di https://www.dw.com/en/covid-19why-is-chinas-vaccination-rate-so-low/a-57183859

Zhang, Zhexin. (2018). The Belt and Road Initiative: China's New Geopolitical Strategy? Stiftung Wissenschaft und Politik. Diakses 7 Mei tersedia di DOI: 10.1142 / S23777400185002401

Zhao, Shuiseng. (2021). Why China's vaccine diplomacy is winning. Diakses pada 7 Mei, tersedia di https://www.eastasiaforum.org/2021/04/29/why-chinas-vaccinediplomacy-is-winning/ 